Original Article

\title{
Potency of endophytic fungi from Nauclea orientalis L. as antioxidant producer
}

\author{
Elisa Nurnawati, Hary Widjajanti*, Vivi Hendra Sutandar, Maulida Harwati, Eka Amelia, Siti Alharzsa, Nina Tanzerina
}

Biology Department, Faculty of Mathematics and Natural Sciences, Sriwijaya University, Indonesia

Abstract

Nauclea orientalis L. is widely distributed in Indonesia. Secondary metabolites such as flavonoids, polyphenols, and saponins are abundant in the bark of $N$. orientalis L. These compounds have the potential to act as antioxidants. Endophytic fungi, through genetic transfer and coevolution, can produce the same metabolites as their host plant. As a result, understanding the potential of endophytic fungi from $N$. orientalis L. to produce antioxidant compounds that can be developed is critical. According to the findings of this study, twelve isolates have the potential to produce secondary metabolites with antioxidant properties. Three isolates had high antioxidant activity: DB2 was identified as Aspergillus minisclerotigenes with an IC 50 of 21 g/mL containing tannins, terpenes, and flavonoids, $\mathrm{AB} 3$ as Colletotrichum perseae with an $\mathrm{IC}_{50} \mathrm{of} 31 \mathrm{~g} / \mathrm{mL}$ containing tannins and terpenoids, and $\mathrm{AB} 1$ as Diaporthe tulliensis with an $\mathrm{IC}_{50}$ of $48 \mathrm{~g} / \mathrm{mL}$ containing tannins, The secondary metabolite group has the potential to be developed into an antioxidant agent.

Keywords: Antioxidant, Aspergillus minisclerotigenes, Colletothrichum perseae, Diaphorthe tulliensis, Endophytic Fungi, Nauclea orientalis L

Received: June 4, 2021 Revised: November 8, 2021 Accepted: November 9, 2021

\section{Introduction}

Based on culture and experience, plants have been widely used as ingredients in traditional medicine. It is due to the presence of active compounds that can be the main component of the drug. In Indonesia, Nauclea orientalis L. is popularly referred to as a gempol plant. In contrast, in Central Sulawesi, this plant is known as lokinda, and in Kalimantan and Sumatra, it is known as the bengkal (Tuheteru et al., 2014). Flavonoids, polyphenols, and saponins are abundant in the bark of $N$. orientalis L. (Saefudin and Basri, 2016). According to research by Wali et al. (2018), the stem base of $N$. orientalis L. contains 17 secondary metabolites. Six compounds at the middle of the stem and 19 at the ends. These secondary metabolites include phenols, phenolic acids, phenolic essential oils, terpenes, and tannins. Squalene (terpene), geraniol (terpene), stigmasta (terpene), and hexadecanoic acid (fatty acids) are some of the active compounds found in three parts of bark. Several secondary metabolites have antioxidant and antibacterial properties.

Endophytic fungi live intracellularly in healthy plant tissues and form symbiotic relationships with their hosts (Stone et al., 2000). Endophytic fungi produce a variety of secondary metabolites with diverse biological activities, including antimicrobial, anticancer, antioxidant, antituberculosis, antiparasitic, antiviral, immunomodulatory, and insecticide properties (Kaul et al., 2012). Through genetic transfer mechanisms,

* Corresponding Author:

Hary Widjajanti

Biology Department, Faculty of Mathematics and Natural

Sciences, Sriwijaya University, Jalan Palembang-Prabumulih,

Km 32 Inderalaya Ogan Ilir 30662.

Phone/Fax :0711-580056

E-mail: haryunsri@yahoo.com endophytic fungi can produce the same secondary metabolites as their hosts (Rachman et al., 2018). According to Dao et al. (2015), an extract from the stem of $N$. orientalis L. had a significant ability to reduce DPPH free radicals as well as lipid peroxidase inhibitor activity. Alkaloids, terpenoids, simple phenolics, coumarin glucosides, anthraquinones, and lignans were among the compounds isolated.

Extraction methods with specific solvents are used to separate secondary metabolites from fungi. Many compounds found in polar solvents like methanol or ethanol have the potential to act as antioxidants (Do et al., 2013; Hameed et al., 2017). Smith et al. (2015) discovered that methanol extract of fungi was more effective as an antioxidant. .Furthermore, the solvent most commonly used to extract the active compound is ethyl acetate, which is semipolar (Santoso et al., 2012). Because the use of large plant parts can reduce the number of plants, endophytic fungi can be used as an appropriate replacement for plant parts. As a result, this research looks into the antioxidant potential of metabolites from the endophytic fungus $N$. orientalis L.

\section{Methods}

\section{Sampling}

Bengkal (Nauclea orientalis L.) was taken in Kampung Sungai Pedada, Keramasan, Kertapati District, Palembang City, South Sumatra. Geographically, the sampling location is S $3^{\circ} 1^{\prime} 42.68352 "$ and E 104.720194". The bengkal plant that were used as samples were the root, leaves and bark taken from the branching of the stem. 


\section{Isolation endophytic fungi}

Each sample was washed with running water and cut into $2 \times 1 \mathrm{~cm}$ pieces. All samples' surfaces were sterilized for 1 minute with 5\% sodium hypochlorite $(\mathrm{NaOCl})$ and then for 1 minute with $70 \%$ alcohol. Finally, the sample was rinsed twice with sterile distilled water for one minute each and dried on sterile tissue. Each sample was aseptically placed on solid PDA (Potato Dextrose Agar) media in a petri dish and incubated at room temperature until fungal growth was observed. Purification was performed on fungal colonies that had grown and displayed various morphological characteristics (Kusumawardhani et al., 2015).

\section{Cultivation and secondary metabolites extraction of endophytic fungi}

Fungal isolates were inoculated on $500 \mathrm{~mL}$ PDB (Potato Dextrose Broth) medium and incubated at room temperature for 35 days under static conditions. Cultivation is carried out in duplicate. The fungal biomass was separated from the medium after incubation. For $24 \mathrm{~h}$, the filtrate was extracted liquid-liquid (partition) with ethyl acetate $(1: 1)$. Finally, the solution is separated from the solvent by a rotary evaporator. The biomass was dried in a $40^{\circ} \mathrm{C}$ oven for $3 \mathrm{~h}$ before being weighed. The biomass was then ground and extracted for two days with methanol. The mixture was then filtered, and the solution was removed, yielding a thick extract (Hasiani et al, 2015; Tan et al., 2018).

\section{Qualitative test of antioxidant activity}

Each extract and ascorbic acid (control) were spotted on the TLC plate as much as $\pm 5 \mu \mathrm{L}$ extract and with \pm 1.5 $\mathrm{cm}$ gap between each isolates. To determined antioxidant activity was conducted by spraying TLC plate with DPPH $0.1 \mathrm{mM}$. isolates selection were done with comparing the closest color spots of the isolates to yellow spot with purple background of ascorbic acid.

\section{Antioxidant activity test with DPPH method}

Variationt of extract concentrations were made by solvent dilution with concentration of 200, 100, 50, 25, $12.5,6.25$ and $0 \mu \mathrm{g} / \mathrm{mL}$. Next, $0.2 \mathrm{~mL}$ concentration of sample solution was added with $3.8 \mathrm{~mL}$ of DPPH 0.1 $\mathrm{mM}$ solution. Then, the mixture was homogenized and let for $30 \mathrm{~min}$ in dark place. Absorbance then measured with spectrophotometer UV-Vis in $\lambda$ maks $517 \mathrm{~nm}$. Standard antioxidant which was ascorbic acid as control positive with same treatment to the samples (Pratiwi et al., 2014). The percentage of inhibition of DPPH free radical activity was calculated using the equation (Mu'nisa et al., 2012):

$$
\begin{array}{ll}
\text { inhibition percentage }= & \frac{A_{k}-A_{s}}{A_{k}} \times 100 \\
\text { Ak: absorbance control } & \text { Positive control: ascorbic acid } \\
\text { As: absorbance sample } & \text { Negative control: ethanol } \\
\mathrm{IC}_{50} \text { value then determine } & \text { using the linear regression equation } \\
\text { (Hasanah et al., 2017) : } & \\
\mathrm{Y}=\mathrm{a}+\mathrm{bX} & \\
\mathrm{Y}=50 & \mathrm{a}=\text { gradients } \\
\mathrm{X}=\text { sample consentration } & \mathrm{b}=\text { constants }
\end{array}
$$

\section{TLC Analysis}

Extracts were spotted on the TLC plate and eluted with n-hexane and ethyl acetate $(1: 2)$. The plate sprayed with $\mathrm{H}_{2} \mathrm{SO}_{4} 10 \%$. Chromatogram pattern on the plate observed under UV lights. Based on Rusnaeni et al. (2016), Rf was calculated using the equation:

$$
R f=\frac{\text { compound distance from spot starting points }}{\text { solvent distance from spot starting points }}
$$

\section{Characterization and identification of fungi}

Endophytic fungal isolates with high $\mathrm{IC}_{50}$ values were inoculated on solid PDA, Malt Extract Agar (MEA), and Czapex Dox Agar and incubated for seven days at room temperature. The morphological characteristics of the fungus were examined based on the macroscopic and microscopic characters of each isolate and then identified based on Barnett and Hunter (1998). Molecular identification was performed by extracting DNA, amplifying the ITS region using ITS1 and ITS4 primers, then sequencing at Macrogen, Korea. Sequencing results were edited and merged using Chromas. MEGA X was used for the phylogenetic tree reconstruction.

\section{Results}

\section{Isolation endophytic fungi}

Based on the isolation and purification results, 12

\begin{tabular}{|c|c|c|c|}
\hline No. & Sample & Code & Number of isolates \\
\hline \multirow[t]{4}{*}{1.} & Root & $\mathrm{AB} 1$ & 4 \\
\hline & & $\mathrm{AB} 2$ & \\
\hline & & $\mathrm{AB} 3$ & \\
\hline & & $\mathrm{AB} 4$ & \\
\hline \multirow[t]{4}{*}{2.} & Leaf & DB1 & 4 \\
\hline & & DB2 & \\
\hline & & DB3 & \\
\hline & & DB4 & \\
\hline \multirow{4}{*}{3.} & & BB1 & 4 \\
\hline & Stem & BB2 & \\
\hline & & BB3 & \\
\hline & & BB4 & \\
\hline & Total & & 12 \\
\hline
\end{tabular}
fungi isolates were collected from the roots, bark, and leaves of $N$. orientalis L. (Table 1). Because the fungal isolates had different morphologies, the species were also different. Endophytic fungi are known to live in plant tissues, so that all isolates can be obtained from all plant organs.

Table 1. Endophytic fungal isolate isolated from Nauclea orientalis L. 


\section{Cultivation and secondary metabolites extraction}

Fungal secondary metabolites were successfully extracted from the filtrate and biomass (Table 2). Table 2 shows no correlation between fungal biomass and the weight of ethyl acetate extract and methanol extract. Because the fungal isolates differed in species (Table 1), their growth patterns and metabolism differed as well.

Table 2. Result of Cultivation of Endophtyic Fungi from Bengkal Nauclea orientalis L.

\begin{tabular}{|c|c|c|c|c|}
\hline No & Isolate Codes & Dried Biomass Weight (g) & Ethyl Acetate Extract Weight(g) & Methanol Extract Weight (g) \\
\hline 1. & BB4 & 3.77 & 0.43 & 0.36 \\
\hline 2. & DB3 & 2.7 & 0.31 & 0.36 \\
\hline 3. & AB2 & 4.3 & 0.22 & 0.68 \\
\hline 4. & $\mathrm{AB} 1$ & 4.25 & 0.34 & 0.37 \\
\hline 5. & BB3 & 3 & 0.76 & 0.81 \\
\hline 6. & DB4 & 1.8 & 0.57 & 0.36 \\
\hline 7. & $\mathrm{AB} 4$ & 3.03 & 0.55 & 1.65 \\
\hline 8. & $\mathrm{AB} 3$ & 2.59 & 0.23 & 1.35 \\
\hline 9. & DB1 & 5.03 & 0.33 & 1.44 \\
\hline 10. & DB2 & 2.31 & 0.31 & 0.56 \\
\hline 11. & BB2 & 2.56 & 0.31 & 0.38 \\
\hline 12. & BB1 & 2.26 & 0.18 & 1.54 \\
\hline
\end{tabular}

\section{Antioxidant Activity of Secondary Metabolites Extract of Endophytic Fungi}

The ability of fungal isolates as antioxidant producers were analyzed by two methods, qualitative and quantitative methods. Qualitative analysis needs to be done to select fungal isolates that potentially produce antioxidant compounds before proceeding with quantitative analysis using a spectrophotometer to obtain the $\mathrm{IC}_{50}$ value. Based on Figure 1, it can be seen that all extracts produced a yellow color on a purple background with different color intensities. This result indicated that the fungal isolates could produce antioxidant compounds qualitatively.

The weight of the extracts, both ethyl acetate and methanol, was unrelated to the antioxidant activities of the compounds contained in them. Table 2 shows that the isolate with the highest extract weight, isolate BB3 for ethyl acetate extract, has low antioxidant ability (Table 3 ). In contrast, the methanol extract of biomass isolate AB4 demonstrated a positive correlation between high antioxidant capacity and extract weight. This condition indicates that the class of active compounds is critical in secondary metabolite activity.

Qualitative analysis was conducted using spectrophotometry. The result of the spectrophotometric method is the percentage of inhibition. Then, we analyzed the percentage of inhibition to obtain the $\mathrm{IC}_{50}$ value. $\mathrm{IC}_{50}$ will shows which extract had strong and very strong antioxidant activity.

According to the quantitative analysis in Table 3, the ethyl acetate extract of three isolates, AB1, AB3, and DB2, had very strong antioxidant activity when compared to ascorbic acid as a control. Isolate AB4 has

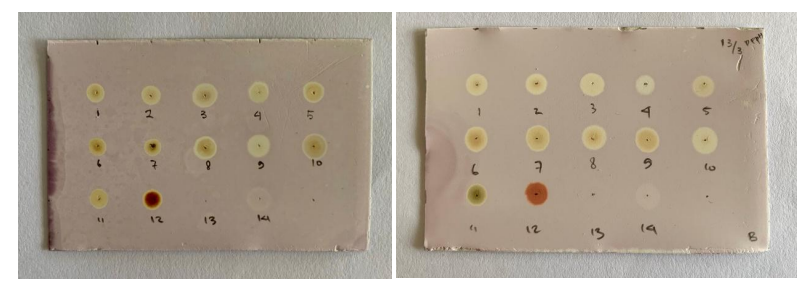

Figure 1. TLC profile extract of endophtyic fungi ( $N$. orientalis L.) eluted with ethyl acetat: $\mathrm{n}$-hexane (2:1). (A. filtrate, B. Biomass, 1 . $\mathrm{BB} 4$, 2. $\mathrm{DB} 3$, 3. $\mathrm{AB} 2$, 4. $\mathrm{AB} 1$, 5. $\mathrm{BB} 1$, 6. $\mathrm{DB} 4$, 7. $\mathrm{AB} 4$, 8. $\mathrm{AB} 3$, 9 . DB1, 10. DB2, 11. BB2, 12. BB1, 13. Ethyl acetate(A) methanol(B), 14. Ascorbic acid.)

strong antioxidant abilities in both methanol and ethyl acetate extracts, whereas isolates BB2 and BB4 have strong antioxidant abilities only in ethyl acetate extracts. Except for isolate AB4, all biomass extracts of fungal isolates had weak antioxidant abilities - inactive based on the $\mathrm{IC}_{50}$ value. This condition is most likely caused by improper extraction of secondary metabolite compounds that act as antioxidants.

Thin layer chromatography secondary metabolites extract of endophytic fungi (Nauclea orientalis 1.)

Based on Table 3, crude extract of BB4, AB1, AB4, AB3 and DB2 was analysed with TLC. Separation of the compound are conducted to know compound types with ability as antioxidant. Figure 2 showed several different color pattern on top of the TLC plate. The color differences are affected by different types of compound inside each extract hence when separated by eluted TLC it will separated. 


\begin{tabular}{clllll}
\hline Table 3. IC $\mathrm{C}_{50}$ Value Secondary Metabolite Extracts of Endophytic Fungi & & \\
\hline No & Isolate Codes & Filtrate & & Biomass & \\
\cline { 3 - 6 } & & $\mathrm{IC}_{50} \mu \mathrm{g} / \mathrm{ml}$ & Activity & $\mathrm{IC}_{50}(\mu \mathrm{g} / \mathrm{ml})$ & Activity \\
\hline 1. & BB4 & 75 & Strong & $1.08 \times 10^{3}$ & Inactive \\
2. & DB3 & 119 & Moderate & $1.58 \times 10^{9}$ & Inactive \\
3. & AB2 & 189 & Weak & 314 & Inactive \\
4. & AB1 & 48 & Very Strong & $1.35 \times 10^{9}$ & Inactive \\
5. & BB3 & 220 & Very Weak & $3.61 \times 10^{5}$ & Inactive \\
6. & DB4 & 127 & Moderate & 776 & Very Weak \\
7. & AB4 & 54 & Strong & 97 & Strong \\
8. & AB3 & 32 & Very Strong & 885 & Very Weak \\
9. & DB1 & 587 & Very Weak & $5,40 \times 10^{3}$ & Inactive \\
10. & DB2 & 21 & Very Strong & 667 & Very Weak \\
11. & BB2 & 88 & Strong & 106 & Moderate \\
12. & BB1 & 206 & Very Weak & $9.20 \times 10^{4}$ & Inactive \\
13. & Ascorbic acid (control) & 17 & Very Strong & 17 & Very Strong
\end{tabular}

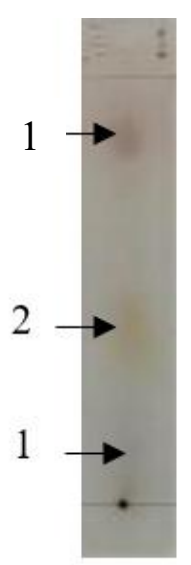

a

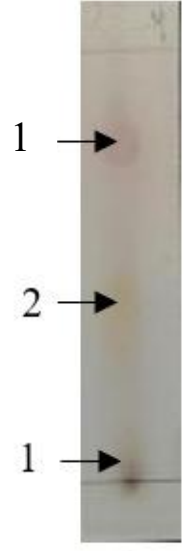

b

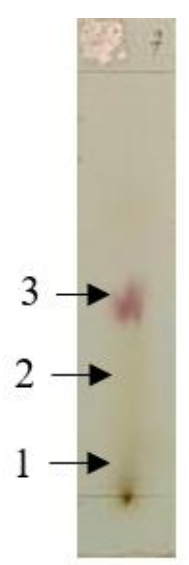

c

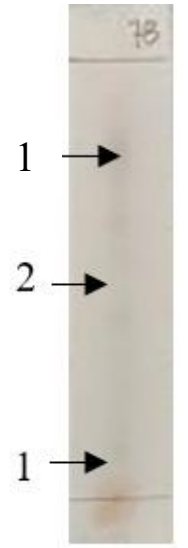

d

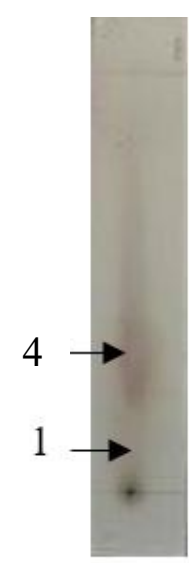

$\mathrm{e}$

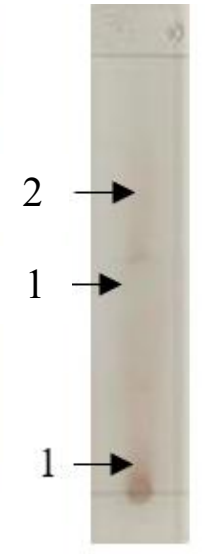

$\mathrm{f}$

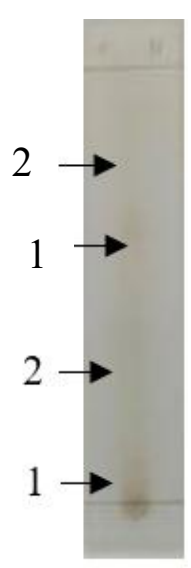

g

Figure 2. Chromatogram of crude extract of endophytic fungi. (a. BB4, b. AB1, c. AB4, d. AB4 biomass, e. AB3, f. DB2, g. BB2. 1. Tannin, 2.Flavonoid, 3. Terpenoid, 4. Alkaloid)

\section{Characterization and identification of potential fungi}

Based on the antioxidant activity test, three isolates were known to possess very strong potential. Fungal isolates were characterized at the macroscopic and microscopic levels. Figure 3 depicts the results of the description.

On PDA medium, a greyish white colony of AB1 isolate with a diameter of $4.5 \mathrm{~cm}$, reverse colored in brown and white on the edges. Growth of an AB1 isolate on CDA, with delicate mycelium. Microscopic characteristics of isolate AB1 had several features that are thin and hyaline septate hyphae. A 100x magnification examination reveals the presence of hyaline and cylindric conidia (Fig.3A).

Colony AB3 isolate on PDA medium was white, with a diameter of $3.2 \mathrm{~cm}$ and a reverse color of white (Fig.
3B). On PDA, AB3 growth was moderate, but on CDA and MEA, the medium around the colony is yellow. The microscopic characteristics of isolate AB3 included hyaline septate hyphae and thin hyphae. Many conidia found with shape are cylindric and hyaline.

On PDA medium, the colony color of DB2 isolate is green with a white shade and white reversed. On PDA, the colony diameter was $4.5 \mathrm{~cm}$ (Fig. 3C). Growth of DB2 isolates on CDA and MEA was slower than growth on PDA. Microscopic features of isolate DB2 at 100x magnification include hyaline septate hyphae, conidia visible and colored in green, conidia and conidiophores abundant and visible, and conidia shaped in an ellipse. All isolates were incubated at room temperature for seven days. The identification of the three fungi isolates 
was advanced using molecular data with ITS1 and ITS4 primers. BLAST analysis (Table 4) revealed that isolates of fungi $\mathrm{AB} 1, \mathrm{AB} 3$, and $\mathrm{DB} 2$ were recognized as member of the genera Diaporthe, Colletotrichum, and Aspergillus, with an identity percentage greater than 98 percent

Table 4. BLAST analysis of ITS region fungal isolate

\begin{tabular}{lclc}
\hline No & Fungal isolate & Refferences species from Genbank & Identity (\%) \\
\hline 1 & AB1 & Diaporthe tulliensis BRIP 62248a & 99.65 \\
& & Diaporthe tectonae MFLUCC 12-0777 & 99.09 \\
\hline 2 & AB3 & Colletotrichum aenigma ICMP 18608 & 100.00 \\
\hline 3 & Colletotrichum perseae CBS 141365 & 99.65 \\
& DB2 & Aspergillus minisclerotigenes strain CBS 116735 & 98.94 \\
& & Aspergillus aflatoxiformans isolate DTO 228-62 & 98.34
\end{tabular}

A
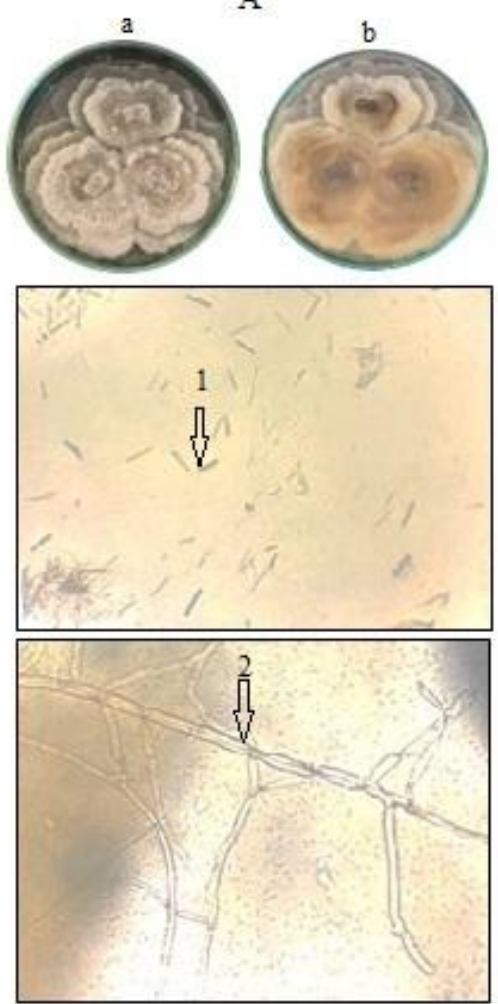

B

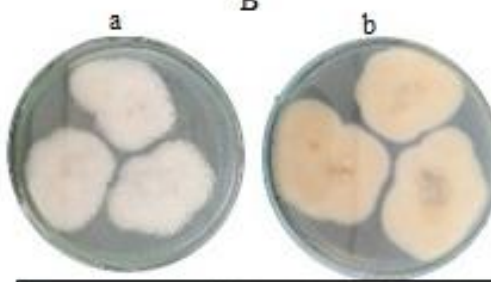

19
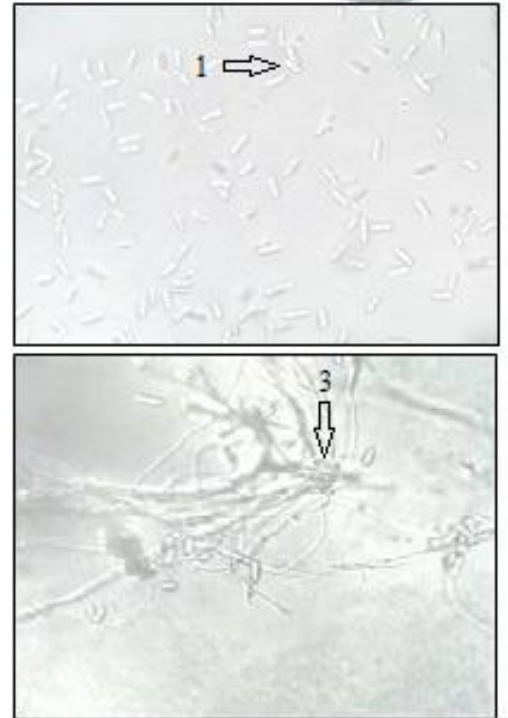

$\mathrm{C}$
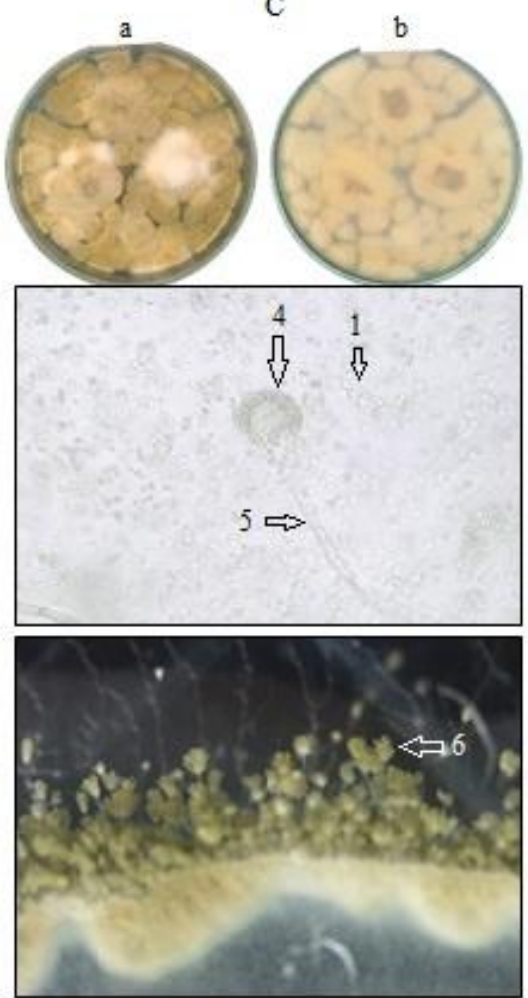

Figure 3. Fungal isolates with the potential to produce very strong antioxidant compounds. (A. AB1, B. AB3, C. DB2, Colonies on PDA incubated for 7 days. a. top, b. reverse. 1. Conidia, 2. Septat hyphae, 3. Conidiogenous cell, 4. Vesicle, 5. Conidiophore, 6. Chain of conidia.)

Figure 4 depicts the construction of a phylogenetic tree based on the ITS region of isolate fungi with very strong antioxidant activity. According to Figure 4, there are three large clusters, I, II, and III. The bootstrap analysis for these three clusters was 100 percent, indicating that this cluster was stable. Cluster I contains isolate AB3 which is a members of the genus Colletotrichum. In cluster I, isolate AB3 was closely related to C. perseae CBS 141365 and had a $99.65 \%$ identity based on BLAST analysis (Table 4). Isolate AB1 was assigned to cluster II, the genus Diaporthe, and was found to be related to D. tulliensis BRIP 62248a. Cluster III belongs to the genus Aspergillus, which contains isolate DB2. A. minisclerotigenes CBS116735 is related to isolate DB2. Cluster III is a member of the Aspergillus section Flavi. The three isolates' morphological data revealed a match with each related species. 


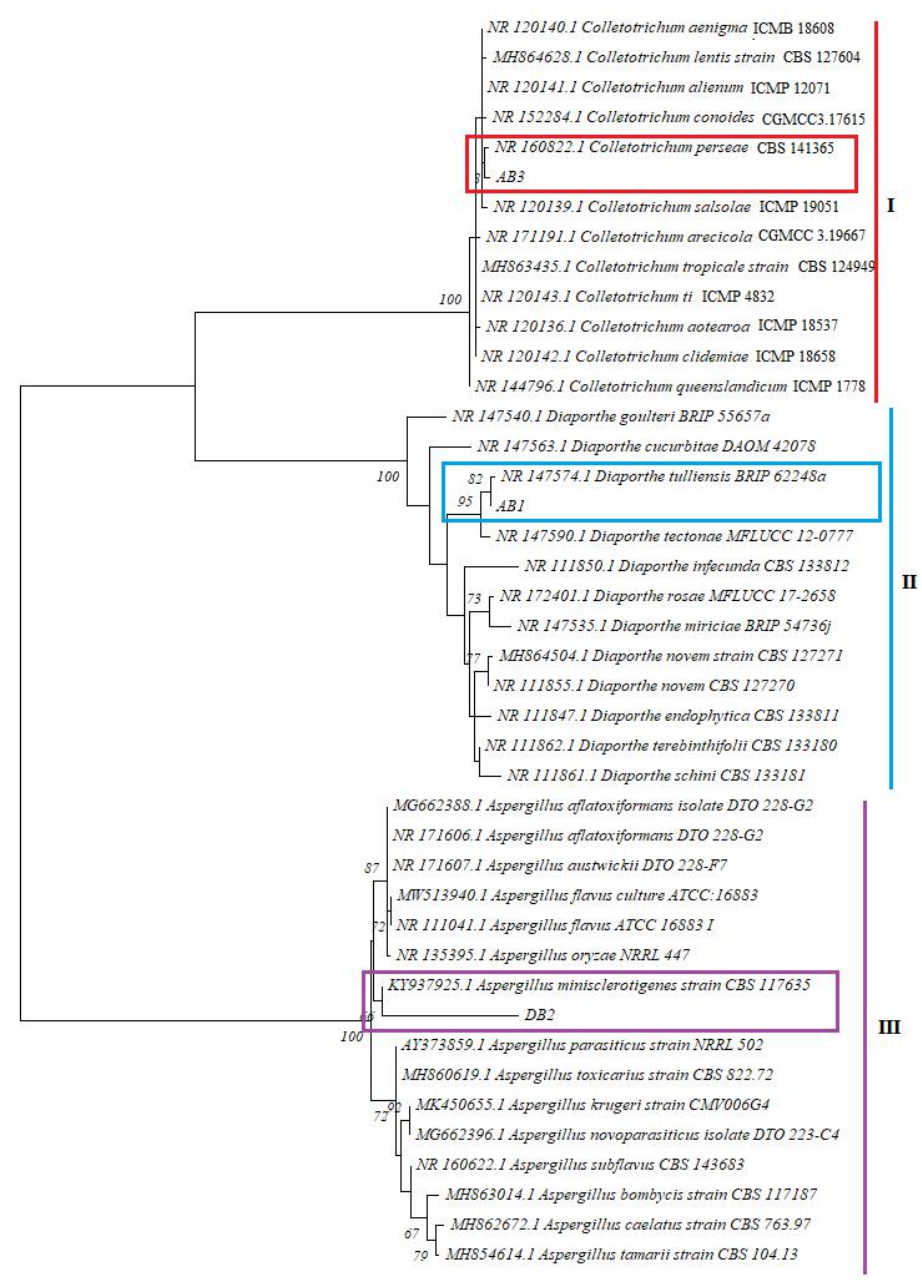

Figure 4. The phylogenetic tree of endophytic fungal isolates with reference strain based on the Maximum Likelihood algorithm with Kimura 2 parameters. The numbers in each branch indicate bootstrap

\section{Discussion}

Endophytic fungi from $N$. orientalis L. have been isolated in a total of 12 isolates. Differences in endophytic fungi colonizing plant tissues can be influenced by the plant tissues' ability to provide the fungi with the nutritional needs they require. Furthermore, it is influenced by fungi's ability to adapt to the environmental conditions of their host plants. Fungi use the nutrients supplied by the host plant as an energy source for growth and development (Sopialena et al., 2018). Because of this condition, the fungal isolates found in each plant differ (Murdiyah, 2017)

Each isolate of endophytic fungi differed in mycelium development, extract weight, and dry weight of biomass (Table 2). These variation occur because each isolate has a unique genome and physiological properties. Secondary metabolite production is controlled by specific genes in each species or group of fungi. Fungi in the Kingdom Ascomycota have more genes than other groups, such as polyketide synthase (PKS) and nonribosomal protein synthase (NRPS). Secondary metabolites are typically species-specific and arise from primary metabolic intermediates (Alurappa et al., 2018; Collemare et al., 2008).

The class of secondary metabolite produced by each species differs due to the secondary metabolites that are unique to each fungal species (Figure 2). The group of compounds produced by each fungus determines its antioxidant activity, so the difference in $\mathrm{IC}_{50}$ value in Table 3 represents antioxidant ability. Six fungi, with high- very high antioxidant activity by Molyneux (2004) standards, were able to produce tannins and the majority of flavonoids. Both of these groups of compounds are found in polyphenols, which are known to have antioxidant properties (Liu et al., 2009). Phenolic and flavonoids have antioxidants properties for anti-allergy and anti-inflammation (Huyut et al., 2017). According to Diaz et al. (2012), bioactive extracts of herbs with high phenolic compound and flavonoid content have very strong antioxidant activity. Tannin is a secondary metabolite that has astringent, antidiarrheal, antibacterial, and antioxidant properties (Desmiaty et al. 2008).

Terpenoid compounds are found in AB4 isolate, which has strong antioxidant activity. Terpeneoids can act as antioxidants by scavenging free radicals and inhibiting lipid peroxidation (Graßmann, 2005). 
Diaporthe tulliensis AB1 contains alkaloids as one of its constituents. Nuraini et al. (2019) discovered a class of endophytic fungi alkaloid compounds with antioxidant properties. Diaporthe sp. has been reported to produce phenolic compounds that are antioxidants (Tanapichatsakul et al., 2017), only in this study, there were no phenolic compounds but tannins and flavonoids. Further research is needed in using methanol as a solvent that potential to bind antioxidant compounds as well as optimization of the potential isolates.

\section{Acknowledgement}

The publication of this article was funded by DIPA of Public Service Agency of Universitas Sriwijaya 2020.SP DIPA-023.17.2.677515/2020, revision 01, on March 16, 2020. In accordance with the Rector's Decree Number : 0684/UN9/SK.BUK.KP/2020, on July 15, 2020.

\section{References}

Alurappa R., Chowdappa S., Narayanaswamy R., Sinniah U.R., Mohanty S.K., Swamy M.K. 2018. Endophytic Fungi and Bioactive Metabolites Production: An Update. In: Patra J., Das G., Shin HS. (eds) Microbial Biotechnology Springer, Singapore. https://doi.org/10.1007/978-98110-7140-9 21.

Barnett, H.L., Hunter, B.B. 1998. Illustrated General of Imperfect. America : Burger Publshing Company. vi $+240 \mathrm{hlm}$.

Collemare, J., Billard, A., Böhnert, H. U., Lebrun, M.-H. 2008 Biosynthesis of secondary metabolites in the rice blast fungus Magnaporthe grisea: the role of hybrid PKS-NRPS in pathogenicity. Mycology Resources. 112, 207-215. doi: 10.1016/j.mycres.2007.08.003

Dao, P. T. A., Quan, T. L., Mai, N. T. T. 2015. Constituents of the Stem of Nauclea orientalis. Natural Products Communications 10(11):1901-1903.

Desmiaty, Y., Ratih, H. Dewi, M.A., Agustin, R. 2008. Penentuan Jumlah Tanin Total pada Daun Jati Belanda (Guazuma ulmifolia Lamk) dan Daun Sambang Darah (Excoecaria bicolor Hassk.) Secara Kolorimetri dengan Pereaksi Biru Prusia. Ortocarpus 8: 106-109.

Diaz, P., Jeong, S. C. Lee, S., Khoo, C., Koyyalamudi, S. R. Antioxidant And Anti-Inflammatory Activities Of Selected Medicinal Plants And Fungi Containing Phenolic And Flavonoid Compounds. Chinese Medicine 7(1):26-34

Do, Q.D., Angkawijaya, A.E., Tran-Nguyen, P.L., Huynh, L.H., Soetaredjo, F.E., Ismadji, S., Ju, Y.H. 2014. Effect of extraction solvent on total phenol content, total flavonoid content, and antioxidant activity of Limnophila aromatica. Journal of Food and Drug Analysis. 22(3): 296 - 302. https://doi.org/10.1016/j.jfda.2013.11.001

Graßmann, J. 2005. Terpenoids as Plants Antioxidants. Vitamin and Hormon 72:505-535

Hameed, A., Hussain, S.A., Yang, J.H., Ijaz, M.U., Liu, Q., Suleria, H.A.R., Song, Y., 2017. Antioxidants potential of the filamentous fungi (Mucor circinelloides). Nutrient. 9(10), 1101; https://doi.org/10.3390/nu9101101

Hasanah, M., Maharani, B., Munarsih, E. 2017. Daya Antioksidan Ekstrak Dan Fraksi Daun Kopi Robusta (Coffea robusta) Terhadap Pereaksi Dpph (2,2-difenil-1-pikrilhidrazil). Indonesian Journal of Pharmaceutical Science and Technology 4(2):42-49.

Hasiani, V. V., Ahmad, I., Rijai, L. 2015. Isolasi Jamur Endofit Dan Produksi Metabolit Sekunder Antioksidan Dari Daun Pacar (Lawsonia inermis L.). Jurnal Sains dan Kesehatan 1(4):146-153.

Huyut, Z., Beydemir, S., Gulcin, I. 2017. Antioxidant and Antiradical Properties of Selected Flavonoids and Phenolic Compounds. Biochemistry Research International 2017:1-10.
Kaul, S., Gupta, M. A., Dhar, M. K. 2012. Endophytic Fungi from Medicinal Plants: A Treasure Hunt for Bioactive Metabolites. Phytochemistry Reviews 11(4):487-505.

Kusumawardani, Y., Liliek, S., Abdul, C. 2015. Potensi Antagonis Jamur Endofit Pada Tanaman Lada (Piper nigrum L.) Terhadap Jamur Phytophora capsici Leionian Penyebab Penyakit Busuk Pangkal Batang. Jurnal Hama dan Penyakit Tumbuhan. 3(1) : 21-29.

Liu S.C., Lin, J.T., Wang, C.K. 2005. Antioxidant properties of various solvent extracts from lychee (Litchi chinenesis sonn.) flowers. Food Chemistry. 114:577-581.

Mu'nisa, A., Wresdiyati, T., Kusunorinin, N., Manalu, W. 2012. Aktivitas Antioksidan Ekstrak Daun Cengkeh. Jurnal Veteriner 13(3): 272-277.

Murdiyah, S. 2017. Fungi Endofit Pada Berbagai Tanaman Berkhasiat Obat Di Kawasan Hutan Evergreen Taman Nasional Baluran Dan Potensi Pengembangan Sebagai Petunjuk Parktikum Mata Kuliah Mikologi. Jurnal Pendidikan Biologi Indonesia 3(1):64-71.

Molyneux, P. 2004. The Use Of The Stable Free Radical Diphenylpicrylhydrazyl (DPPH) For Estimating Antioxidant Activity. Journal of Science Technology 26(2):211-219.

Nuraini, F.R., Setyaningsih, R., Susilowati, A., 2019. Antioxidant Activity of Bioactive Compound Produced by Endophytic Fungi Isolated from Endemic Plant of South Kalimantan Mangifera casturi Kosterm. International Conference on Biology and Applied Science (ICOBAS) AIP Conf. Proc. 2120,080013-1-080013-9; ttps://doi.org/10.1063/1.5115751 Published by AIP Publishing. 978-0-7354-1860-8/\$30.00

Pratiwi, D. R., Maria, B., Partomuan, S. 2014. Lelutung Tokak (Tabernaemontana macrocarpa Jack) Sebagai Sumber Zat Bioaktid Antioksidan dan Antikanker. Ilmu Kefarmasian Indonesia 12(2):267-272.

Rachman, F., Mubarik, N. R., Simanjuntak, P. 2018. Aktivitas Antioksidan Ekstrak Kapang Endofit Cb.Gm.B3 Asal Ranting Kayu Manis (Cinnamomum burmanni). Jurnal Bioteknologi dan Biosains Indonesia 5(2):204-213.

Rusnaeni, Sinaga, D. I., Lanuru, F., Payungallo, I. M., Ulfiani, I. I. 2016. Identifikasi Asam Mefenamat Dalam Jamu Rematik Yang Beredar di Distrik Heram Kota Jayapura, Papua. Jurnal Pharmacy 13(1):84-91.

Saefudin., Basri, E. 2016. Potensi Antioksidan dan Sifat Sitoktoksis Ekstrak Kulit Kayu Sembilan Jenis Tumbuhan di Taman Nasonal Lore Lindu. Jurnal Penelitian Hasil Hutan. 34(2): 147-155.

Santoso, J., Anwariyah, S., Rumiantin, R. O., Putri, A. P., Ukhty, N., Yoshie-Stark, Y. 2012. Phenol content, antioxidant activity and fibers profile of four tropical seagrasses from Indonesia. Journal of Coastal Development 15(2): 189-196.

Smith, H., Doyle, S., Murphy, R. 2015. Filamentous fungi as source of natural antioxidants. Food Chemistry. 185:389 - 397 .

Sopialena, S., Suyadi, S., Sahil M, Nurdiana J. 2018. The diversity of endophytic fungi associated with Piper nigrum in the tropical areas: a recent study from Kutai Kartanegara, Indonesia. Biodiversitas 19: 2028-2034.

Stone, J. K., Bacon, C. W., White, J. 2000. An Overview of Endophytic Microbes: Endophytism Defined, p 3-29. in Bacon, C. W. dan White, J. F. 2000. Microbial Endophytes. New York: Marcel Dekker Inc. 500 pp.

Tan, X. M., Zhou, Y. Q., Zhou, X. L., Xia, X. H., Wei, Y., Li, L. H., Tang, H. Z., Yu, L. Y. 2018. Diversity And Bioactive Potential Of Culturable Fungal Endophytes Of Dysosma versipellis; A Rare Medicinal Plant Endemic To China. Science Report 8(1):1-9.

Tanapichatsakul, C, Monggoot, S. Gentekaki, E., Pripdeevech, P. 2017. Antibacterial and Antioxidant Metabolites of Diaporthe spp. Isolated from Flowers of Melodorum fruticosum. Current Microbiology. 75:476-483.

Tuheteru, F. D., Kusmana, C., Mansur, I.., Iskandar. 2014 Karakteristik Buah Dan Mutu Morfo-Fisiologis Benih Lonkida (Nauclea orientalis L.) Dari Habitat Alami Di Sulawesi Tenggara. Jurnal Pemuliaan Tanaman Hutan 8(3):152-160.

Wali, M., Tuharea, M. S., Uar, N. I. 2018. Senyawa Kimia Kayu Marsegu (Nauclea orientalis L.). Jurnal Agribisnis Perikanan 11(2):70-74. 